\title{
MULHER, CASAMENTO E TRABALHO: \\ UM TRIÂNGULO QUE NÃO FECHA?
}

WOMEN, MARRIAGE AND WORK:

A TRIANGLE THAT NEVER CLOSE?

\author{
Maria Beatriz Nader* \\ marxis@terra.com.br
}

ResUMO: Nas últimas três décadas do século $X X$, Vitória passou por mudanças radicais em sua estrutura sociocultural em virtude das transformações econômicas promovidas pela decadência do modelo primário-exportador, do aumento desenfreado de sua população e da implantação de grandes indústrias. A dinâmica econômica que se processou na cidade caracterizou uma sociedade multifacetada, cujo cotidiano sofreu transformações profundas, mudando a vida pacata de seus habitantes, em particular, das mulheres vitorienses. O mercado de trabalho, secundário e terciário, proporcionou-lhes possibilidades até então nunca vistas na cidade. A participação delas no mundo público permitiu-lhes alterar costumes que as atrelavam à família e ao casamento, sendo esse último considerado o objetivo primordial de suas vidas.

PALAVRAS-CHAVE: trabalho - mulher - casamento

ABSTRACT: In the three last decades of the twentieth century, Vitória had undergone radical changes in its sociocultural structure due to economic transformations that were caused by three factors: the decline of its primary exporting model, the uncontrollable growth of its population, and the installation of large-scale industries.

* Professora do Programa de Pos-graduação (mestrado e doutorado) em História Social das Relações Políticas, da UFES e coordenadora do Laboratório de Estudos de Gênero, Poder e Violência. Atualmente coordena o Curso de Pos graduação lato sensu em Gestão de Politicas Públicas em Gênero e Raça.

Maria Beatriz Nader. MULHER, CASAMENTO E TRABALHO 
Because of it, a dynamism in economy had characterized the city as a large town where society had gotten many facets. The people's everyday was profoundly altered: the inhabitants' quiet life had to be change, specially with respect to the women's lives. The secondary and tertiary job market in Vitória had promoted opportunities to the females as never before. The women's involvement in public dimension allowed them to alternate practices which had bound them closely to their families and to the matrimony.

KEY WORDS: work - woman - marriage.

Ocorridas em Vitória, após os anos de 1970, as mudanças econômicas que permitiram o acesso de milhares de trabalhadores e trabalhadoras ao mercado de trabalho que se abriu com a implementação dos Grandes Projetos Industriais (CST, SAMARCO, ARACRUZ CELULOSE e ampliação da CVRD) traçaram profundas transformações na vida da mulher capixaba. Acostumadas que foram à condição de trabalhadoras sem remuneração, seja atuando no espaço doméstico, seja desenvolvendo atividades no campo, em uma sociedade que ainda trazia forte e grandes resquícios da ideologia patriarcal até aqueles anos, as mulheres capixabas, ao ingressarem no mercado de trabalho remunerado, elaboraram novos padrões de conduta, mostraram-se socialmente capazes de gerir seu próprio sustento e o de sua família, além de alterarem o projeto socialmente considerado como o ideal da vida feminina: o casamento. Ou seja, ao se inserirem no mercado de trabalho e deixarem de depender economicamente do pai e/ou do marido, as mulheres passaram a se relacionar de forma diferente com tal instituição.

Milhares de mulheres que se inseriram nas industrias e em todo o mercado de comércio e serviços que se abriram a seguir, não tinha sequer o curso secundário completo. Eram mulheres que foram com suas famílias 
atrás de uma situação econômica que pudesse melhorar sua condição de vida, pois a grande maioria habitava o interior dos Estados do Espírito Santo, de Minas Gerais, da Bahia e do Rio de Janeiro.

Sobre muitas delas, incidia a carga de sustentação do domicílio e também a responsabilidade de se manter diante da sociedade de forma a não expor sua família a situações financeiras desagradáveis. Ingressando no mercado de trabalho, ampliavam-se as possibilidades de prover melhor o domicílio e, mais ainda, de proporcionar garantias de redução das desigualdades econômicas, fato que impunham diferenças dos papéis sexuais, na sociedade e na relação marital. A compreensão desse fenômeno serviu como ponto de partida para a realização da pesquisa ora apresentada. Ao abordar esse tema, intenta-se estabelecer um conjunto de reflexões sobre as diversas mudanças que ocorreram no comportamento da mulher moradora de Vitória, particularmente no tocante à sua relação com o casamento.

\section{O CASAMENTO E AS MULHERES}

Na fase originária da vida social, a personalidade humana esteve sujeita a uma situação de promiscuidade nas relações entre os homens e as mulheres e ao sistema de propriedade, a qual fazia do clã comum um elo homogêneo indefinido. Spencer $(1987,19)$ afirma que esse clã constituiu “[...] o ponto de partida da evolução social" humana. O homem mais poderoso da tribo, travestindo-se da imagem de chefe, fez-se o primeiro centro de formação de personalidades e de direitos dos indivíduos pertencentes ao seu clã. Somente com o aparecimento da propriedade privada, que fragmentou o clã em famílias, é que esse chefe, agora patriarca, passou a representar o centro mais definido de interesses.

Nas culturas em formação, prevaleceu a superioridade masculina, que se traduziu na instituição do patriarcado, fortalecendo o poder 
do chefe que dispunha de todos os membros da família, principalmente das mulheres. Apesar de ser uma instituição contestável, o patriarcado fortaleceu a dominação masculina diante da mulher na história.

À proporção que a civilização se foi desenvolvendo, formaram-se grupos de interesses compartilhados, e cada um, ao seu estilo, necessidade e compreensão, deu ao matrimônio uma definição. Quase todos, porém, atrelaram o papel social da mulher à família, por meio da união conjugal.

Maffre (1989), estudando a Grécia de Platão, afirma que os casamentos de homens livres eram a forma de se dar filhos legítimos à Pátria. Os gregos, seguindo os preceitos do sistema de dominação masculina que se afirmava, entabulavam negociações com o objetivo principal de assegurar a continuidade das famílias e de seus cultos, o que sustentava a desvalorização da mulher, um ser dotado de uma frágil capacidade de deliberação e, por isso, não merecedora de consideração.(BADINTER, 1985)

Em Roma, segundo Veyne (1989), cem anos antes da Era Cristã o casamento era um ato entre famílias. Constituído como um contrato civil no Império Romano, a união entre um homem e uma mulher tornou-se um instrumento de controle básico da transmissão do patrimônio e de acordos familiares. "Era uma situação de fato que criava efeitos de direito", afirma o autor. Nessa sociedade a família foi a princípio admitida com todos os seus rigores, para depois, aos poucos, ir perdendo sua primitiva significação. As pessoas, principalmente as mulheres, estiveram, durante muito tempo, sob a rigidez da configuração da conhecida família romana, na qual se originou oficialmente a opressão da mulher e o nascimento do patriarcado, muito debatido na obra de Engels. (1987)

Privilegiando estudos sobre o gênero feminino na Roma patriarcal, Ciribelli (1985) enfatiza que a mulher na sociedade romana, diante da instituição familiar, ora era vista como esposa honrada, mãe de família e possuidora de grandes virtudes, ora como prostituta, perdida e nociva à 
sociedade. A vida da mulher resumia-se ao ponto de vista de sua biologia, considerada naturalmente inferior ao homem.

Ainda ornados com fortes fragmentos desse pensamento sobre a mulher, o início do cristianismo, o apóstolo Paulo, precursor de idéias sobre a continência e a virgindade que não davam possibilidades nem aos homens nem às mulheres de se libertarem do mundo corrupto e decadente, divulgou mensagens sobre a salvação da alma, afirmando que o corpo deveria manterse casto para que a alma pudesse ser elevada a Deus.(Ver VAINFAS, 1986; BROWN, 1990)

Nas pregações paulinas, o casamento, embora representasse a forma legítima de dar vazão aos desejos do corpo, deveria ser renunciado e os desejos dos corpos, reprimidos. Por suas idéias e, em uma sociedade de cunho ideológico patriarcal, Paulo influenciou de forma tácita o pensamento a respeito do casamento nos padres da Igreja que se iniciava, ou seja, o casamento deveria ser um ato necessário, mas visto como um mal. Era uma oposição à salvação da alma, que necessitava do exercício constante de contemplação.

Assim o casamento foi hostilizado, mas, por outro lado, foi tolerado no seio da nova religião cristã, por ser o espaço alternativo às pessoas que não se continham, que eram incapazes de guardar continência. Foi considerado como uma instituição que moralizava os desejos dos corpos. Como afirmaria Agostinho, tempos depois o "casamento era o pior dos bens".

Para a moralidade sexual pessimista e contraditória de Agostinho, o casamento, ao mesmo tempo que representava um mal, como espaço de manifestação do desejo do prazer carnal, representava um bem, como fonte de procriação. A criança, a fidelidade e a indissolubilidade da união conjugal constituíam os principais bens do casamento, a cuja finalidade deveria subordinar-se integralmente $\mathrm{o}$ ato carnal. Exprimindo seu pensamento a respeito da gênese da vida humana na terra e do relacionamento entre 
homens e mulheres, Agostinho (HIPONA, 1990) colocou-se diante do impasse entre a virgindade e a concupiscência e o casamento. $O$ sexo para ele, mesmo entre os casados, deveria ser um amor sem prazer, principalmente para a mulher, classificada como estimulante, mas nunca como companheira. Para Agostinho, a mulher somente era útil para a reprodução e desqualificada para qualquer outra coisa.

Nesse modelo de convívio marital era fundamental que, no matrimônio cristão, os cônjuges se portassem de forma virginal, ou seja, o casal somente deveria unir-se sexualmente quando tivesse por objetivo a procriação, e a mulher deveria acompanhar a abstinência do marido. Quando o homem tomasse sua esposa, ela deveria conservar-se virgem. Para isso, a mulher não deveria sentir nada enquanto seu marido a 'violentava'.

Dentro desse imaginário, o casamento foi adquirindo princípios de instituição divina por imposição da Igreja Cristã, que criou regras para moldar $\mathrm{o}$ ato a esses princípios. A mulher deveria manter-se virgem até as núpcias e depois atender aos desejos do marido. Com essas normas, a intervenção eclesiástica na união entre um homem e uma mulher se fazia presente, embora de forma ainda incipiente e complicada, pois os teólogos medievais não conseguiam aceitar a santificação do casamento, uma vez que ele implicava relações sexuais entre os cônjuges. (VAINFAS, 1986)

Contudo, no século XII, a Igreja Católica transformou o casamento em um dos sete sacramentos cristãos e passou a controlar os princípios sociais basilares, de forma a coordenar todos os comportamentos sociais dos homens e das mulheres. A sacralização do casamento tinha entre seus objetivos defender o valor da sexualidade e focalizar o consentimento conjugal. Desta forma a Igreja Católica apropriou-se da exclusividade da jurisdição do casamento, pois uma vez transformado em sacramento, o casamento seria um remédio contra o pecado, embora fosse um sacramento que não conferia graça, ao contrário do batismo, da eucaristia e do sacerdócio. 
Aquino reconhecia que o casamento era um sacramento que propiciava as relações carnais, excluindo a castidade e admitindo o pecado da carne. Transfigurava-se em mistério cristológico, afirma Vainfas (1986).

Em meados do século XVI, o Concílio de Trento incluiu o casamento definitivamente dentro do pensamento católico como um instrumento sagrado, necessário e uniformizado, assumindo assim a iniciativa de sua ordenação. O Concilio promulgou tal ordenação como lei para a Igreja Universal.

Dentro do projeto de renovação da Igreja, cuja característica principal era a crença de que o indivíduo poderia e deveria cooperar com Deus e de que a fé cristã deveria ser mais bem vivenciada na atividade terrena, os conciliares entenderam que a vontade humana não era meramente passiva nem escrava do pecado, mas sim chamada a colaborar para a obra divina, afirma Davidson (1991). E, diante dessa abordagem, decidiram que a concupiscência era um incentivo ao pecado, embora em si mesma não fosse um obstáculo intransponível. Mas, para evitar o pecado do desejo da carne, somente a união conjugal controlada pela Igreja seria a solução. Foram, então, instruídas medidas, como o Decreto de reformatione matrimonti, que disciplinavam as relações sexuais dos indivíduos e, a principal delas, foi o casamento sacramental, ferramenta de luta para indivíduos que não conseguiam viver em castidade. O matrimônio tornou-se uma instituição obrigatória, dentro de moldes bem definidos, que deveria realizar-se na presença de um pároco ou de um vigário.

Segundo Mullet, (1984) o Concílio de Trento, que começou com um longo período preparatório de preocupação e esforço, depois de terminado, infiltrou suas normas nos costumes e nas instituições de forma muito lenta, mas eficaz. A vida das famílias, as relações entre marido e mulher e entre pais e filhos, e aspectos da vida social diária da comunidade foram controlados por regras e conselhos que definiam comportamentos 
de convivência doméstica. Segundo o autor, seus ensinamentos implicaram reformas do ensino nas escolas, orientadas principalmente pelo princípio jesuítico da formação do adulto, por meio da educação inicial da criança, tanto nas escolas jesuíticas para meninos, como nas escolas para meninas. (Ver também DELUMEAU, 1983)

A parte feminina da sociedade ocidental foi a que mais sofreu as influências dos novos ensinamentos religiosos propostos pelos conciliares de Trento. Vistas desde o princípio do cristianismo como um ser perigoso, as mulheres, após o Concílio de Trento, passaram a ser consideradas as guardiãs do cristianismo. Essa mudança de comportamento da Igreja deu-se quando as mulheres, procurando manter a sobrevivência da Igreja na França, levaram suas rezas para o ambiente doméstico, espalhando na vizinhança devoções religiosas. A Igreja vislumbrou nesse movimento a forma de levar às famílias a moral cristã.

Dentro do conjunto de estratégias utilizadas pela Igreja para que as mulheres adquirissem uma formação cristã, a educação feminina passou a ser prioridade. Justamente por serem consideradas a base da família, elas precisavam ser preparadas para obedecer, tornar-se totalmente humildes e ter uma formação que as capacitasse para assumir os lares cristãos e oferecer aos filhos uma formação moral baseada no catolicismo.

Um discurso normatizador foi sendo imposto como um processo civilizatório, e várias obras de ensino feminino foram sendo compiladas nos séculos seguintes, estimulando as mulheres a aceitarem seu destino de esposa e mãe, transformando isso no ideal de vida para as mais afeitas à religião cristã.

A mulher tornou-se o alvo principal para que as uniões fossem realizadas dentro do modelo instituído pelo Concílio de Trento. Catecismos e documentos literários, escritos por pessoas que pretendiam disciplinar o comportamento feminino, fizeram da educação um meio de prepará-la para 
o casamento. Muitas medidas foram tomadas com o objetivo de promover a união social entre os sexos, destacando-se dentre elas a instrução familiar, que a mulher, desde pequena, passou a receber. Nesse processo, ela era convencida a querer intensamente o casamento e a gostar dele, mesmo que as conseqüências dessa união não Ihe fossem favoráveis. Logo, tanto a educação doméstica, quanto a escolar instruíam a mulher para aceitar viver ao lado de um homem, dando-Ihe sua vida, seu corpo e sua força de trabalho, assumindo o papel de esposa.

Os séculos de dominação portuguesa no Brasil viram grandes fluxos de pessoas, sobretudo masculinas, buscarem a adaptação ao Novo Mundo. E, para a execução do projeto de Trento e do Governo português, a Igreja Católica, a serviço do Estado, desenvolveu os projetos reformistas do Concílio de Trento, fundamentando as Constituições Primeiras do Arcebispado da Bahia.

As Constituições buscaram dar ordem às uniões entre homens e mulheres na Colônia e seu texto pregava que o casamento era o único meio cristão de dominar os corpos e legitimar as uniões naturais entre os sexos, e valia-se da mulher para adequar a população aos novos preceitos cristãos, seguindo os mesmos mecanismos usados pela Igreja na Europa.

Nos séculos que seguiram a chegada dos religiosos no Brasil, jornais, catecismos, literatura, propagandas e ensino foram, entre outros, mecanismos utilizados pelos pensadores para transmitir às mulheres o entendimento de que a natureza feminina as conduzia ao casamento e à maternidade. O pensamento católico, que perpassava por todas as camadas da população, cidades e zonas rurais, pregava os valores que a Igreja desejava impor aos fiéis, principalmente às mulheres, a quem restringia o mais possível a ação para dentro dos muros domiciliares.

Durante o século XIX e mesmo com a implantação do sistema republicano, a sociedade brasileira manteve-se presa às pregações da 
moralização dos costumes por meio da instrução, e nela incluíam-se principalmente as mulheres. Prevalecia a idéia de que a educação deveria preparar a mulher para o casamento e a família e não para seu crescimento intelectual.

A moral que preparava a menina para o desempenho das funções domésticas pressionava o comportamento feminino no sentido de a mulher conservar sua honra e não se indispor com a disciplina patriarcal que se manteve na sociedade brasileira até parte do século XX. As normas sociais e naturais dos sexos revelavam valores morais que deviam refletir-se no comportamento feminino de forma a garantir sua honra e sua imagem de moça de família e boa esposa e mãe, devendo tal comportamento prosseguir na viuvez.

Muitos pareceres e considerações foram escritos sobre o comportamento feminino e proferiam, de modo geral, a condição feminina baseada na honra e na virtude, notadamente daquelas que possuíam proteção do pai ou do marido, pois sem a proteção de um homem, a mulher, que carregava o estigma de ser a causa do pecado original, corria sérios perigos de manter ou mesmo fomentar sua natureza maligna.

Sob essa forma de pensar, o casamento firmou-se na sociedade brasileira como a única forma de adestrar a sexualidade feminina, por isso a mulher deveria, desde pequena, ser educada para casar-se o mais cedo possível. As instituições de ensino, de religião e de formação de opinião, em todo o país, repetiam a idéia de que toda mulher desejava casarse, contribuindo para a interiorização desse sentimento em milhares de mulheres. Exemplo disso é a revista $O$ Cruzeiro que, ainda nos anos de 1980, transmitia às mulheres o conhecimento de que a natureza feminina conduzia ao casamento e à maternidade, e, consequentemente, as induzia a ser boa dona-de-casa e submissas ao seu marido. Logo o casamento, um sonho 
feminino, foi reforçado pela crença de que realmente era o único destino das mulheres. (BASSANEZI, 1996)

\section{O MERCADO DE TRABALHO E AS MULHERES.}

Durante todo o período colonial, a terra representou a principal fonte de direitos políticos, e a doação de sesmarias para as mulheres requeria provas de riqueza e poder econômico. Por isso, poucas mulheres conseguiram a posse de terras.

As mudanças políticas que alteraram profundamente as estruturas sociais e econômicas do Brasil, em fins do século XIX, incorporaram milhares de mulheres à nascente força de trabalho assalariado, dando novo significado à presença feminina na sociedade. Até então, no meio urbano, elas somente participavam de pequenos negócios e de variada gama de serviços ligados ao abastecimento. Eram serviços que ofereciam oportunidades para elas ocuparem os espaços deixados pelos homens que migravam em busca de novas frentes de trabalho.

Em todo o Brasil, como a população era predominantemente rural nessa época, as oportunidades de trabalho para as mulheres no campo eram muito restritas, limitando-se às atividades domésticas e agrárias. Também nas cidades, apesar de haver maiores oportunidades de trabalho feminino, havia o agravante da baixa remuneração. Mesmo executando serviços iguais aos dos homens, as mulheres recebiam salários muito menores, e a justificativa dada pelos proprietários das indústrias era, de acordo com Kühner, (1977) a crença de que [...] se [as mulheres] trabalharam até então sem remuneração, contentar-se-iam com menor paga ou mesmo com qualquer preço.

Nem com os avanços tecnológicos advindos com o início da industrialização e com o crescimento das cidades, o panorama do trabalho feminino sofreu grandes modificações. Elas continuaram não tendo acesso às 
profissões mais bem remuneradas, pois essas eram consideradas masculinas por excelência. Assim como nos campos, a discriminação de gênero determinava as ocupações nas cidades.

Eram poucas as oportunidades de trabalho assalariado para as mulheres. Sua presença destacava-se na função de professoras e em estabelecimentos comerciais, nos escritórios e na burocracia. Isso acontecia porque as atividades que assim desempenhavam davam continuidade às ocupações tradicionalmente femininas. Na realidade, eram serviços marginais ao processo de produção e mal pagos.

A literatura disponível sobre trabalho feminino no Brasil, em fins do século XIX e início do XX, mostra que, para burlarem essa desigualdade e fugir à classificação humilhante de serem consideradas inaptas para determinadas tarefas, milhares de mulheres brasileiras, particularmente as casadas, utilizaram seu conhecimento de trabalho manual para ajudar no sustento de suas famílias, ou mesmo para sustentá-las sozinhas. As mulheres que residiam nas cidades desenvolveram trabalhos, em grande parte, dentro da própria casa, improvisando a produção de artigos baratos que faziam por encomendas, ou para venderem nas ruas: doces, brinquedos, charutos, entre outros produtos.

Segundo Albornoz, (1986) as atividades desenvolvidas no âmbito da casa, como a feitura de objetos artesanais, a produção de malhas, de rendas, de tricô e de crochê, se não entravam no conceito de trabalho produtivo segundo o capital, nem devolviam em lucro a força empenhada e os seus custos, com certeza eram usadas pela produtora e por sua família como um trabalho extra para complementar as despesas da casa. Nesse entendimento, o trabalho doméstico que resultava em bem de uso era produtivo em sentido mais amplo, uma vez que também produzia objeto material. 
A mais complexa e também mais importante das atividades manuais realizadas em casa era a costura. Para um grande contingente de mulheres, essa ocupação tornou-se a única opção para o sustento da casa. Recebendo encomendas de variadas fábricas dos ramos têxteis e de vestuário, as mulheres costuravam produtos de cama e mesa, e roupas em geral. A grande produção caseira feminina, no entanto, era a costura de sacos para a embalagem de café.

$E$, o café durante anos foi o principal produto econômico do Brasil. Integrante do rico sudeste cafeeiro, apesar de ser uma das províncias menos desenvolvidas do país, o Espírito Santo conseguiu desbaratar-se de sua letargia, graças à produção do café que se manteve por mais de um século como a principal fonte geradora de rendas do Estado, promovendo também a riqueza de seus produtores.

Entre os anos de 1890 e 1920, o café representou mais de 90\% do valor total das exportações capixabas, chegando a atingir, em 1903, 95\% da receita do Estado. (BITTENCOURT, 1987) Porém, a agricultura local não se dedicava somente à cultura cafeeira, mas também, e em menor escala, ao cacau, ao algodão, à cana-de-açúcar, ao milho e ao arroz. Contudo, o comércio era dedicado prioritariamente à exportação de café.

No final da década de 1910, graças ao capital acumulado pela expansão cafeeira, Vitória, capital do estado do Espírito Santo, começou a passar por uma transformação estrutural, recebendo calçamentos, iluminação elétrica, água encanada, esgotos, escolas e outros serviços públicos básicos, além da criação do Porto de Vitória. Com isso, atraiu grande parte da produção de café de Minas Gerais e do sul do Espírito Santo, que antes era exportado através do Porto do Rio de Janeiro. Casas bancárias e empresas de exportação e importação nacionais, locais e estrangeiras foram abertas. 
Contudo, essas melhorias da cidade e o crescimento econômico do Estado não conseguiram levar o Espírito Santo a alcançar o dinamismo econômico da Região Sudeste, em que se situa geograficamente. Suas próprias características sócio-econômicas o mantinham dentro das mesmas tendências das regiões menos desenvolvidas do país. A situação secundária e desfavorável do Estado, que se mantinha entre a prosperidade sulista e a pobreza nordestina, tinha sua explicação na inexpressiva força política local que manteve, durante várias décadas, o Espírito Santo fora das decisões da política econômica nacional. O modelo econômico primário-exportador do Estado foi ditado pelo café que determinou as atividades de mão-de-obra e a formação da renda no contexto sócio-econômico, até o final da década de 1950. (SIQUEIRA, 2002)

No entanto, foi nesse período que o Estado consolidou sua posição nesse mercado, pois, além do intercâmbio com as regiões importadoras de seus produtos primários e exportadoras de produtos manufaturados consumidos pelos capixabas, passou a ser o principal corredor de exportação do minério de ferro da região de Itabira, em Minas Gerais. A Companhia Vale do Rio Doce (CVRD), criada em 1942 pelo Acordo de Washington, começou a explorar o minério da aludida região mineira e a comercializá-lo nos mercados internacionais, utilizando para tal fim o sistema portuário de Vitória. Nesse contexto, o Governo do Estado, sintonizado com a proposta industrializante conduzida pelo Governo Federal, deu início ao Plano de Valorização Econômica do Espírito Santo, buscando reduzir os obstáculos que poderiam impedir o desenvolvimento do Estado.

Contudo, a economia capixaba precisava modernizar-se e exigia medidas decisivas dos poderes públicos. Para a elite local, a saída estratégica para enfrentar o crescimento industrial do país e fomentar o desenvolvimento estadual não parecia ser outra que não a industrialização. As poucas indústrias que se desenvolviam na capital atraíam a população rural, mas 
não ofereciam empregos o suficiente para atender à demanda de mão-deobra que crescia com o êxodo rural. Acrescente-se a isso a desqualificação do pessoal desempregado e a baixa renda per capita regional, situada aquém da metade da nacional, aproximando os traços econômicos e sociais do Estado com os do Nordeste brasileiro, historicamente sabidos como desiguais e desequilibrados.

Com um esforço político o Governo Estadual conseguiu autorização federal para criar incentivos fiscais que retirariam da economia local os tributos necessários para a construção de um parque industrial, ou seja, o Governo do Estado do Espírito Santo viria a ser o próprio fornecedor de capital social básico para seu progresso. Havia consciência, entretanto, de que somente o capital interno era insuficiente para alavancar o processo de desenvolvimento do Estado, visto que a economia local ainda se caracterizava pela expansão dos gêneros alimentícios tradicionais, situando-se abaixo da média nacional.

Por outro lado, o II Plano Nacional de Desenvolvimento (II PND), lançado pelo Governo Federal em 1974 para enfrentar a crise econômica de então, tinha como objetivo a substituição acelerada das importações no setor de bens de capital e insumos básicos, bem como o desenvolvimento de grandes projetos de exportação de matéria-prima. Para isso, precisava contar com um centro localizado estrategicamente entre as jazidas de minério de ferro e o mar, que oferecesse condições para se formar uma infra-estrutura portuária e ferroviária e estivesse apto a receber grandes investimentos capazes de atender ao mercado externo.

Conjugando esforços na implementação de grandes projetos industriais, os governos federal e estadual viabilizaram uma mudança radical na economia do Espírito Santo, obrigando a este último deixar sua dependência da monocultura cafeeira secular para ligar-se ao grande capital internacional, em menos de uma década. Os chamados Grandes Projetos de 
Impacto, ou Grandes Projetos Industriais, ligados a investimentos estatais e estrangeiros passaram a definir a dinâmica de quase todo o desenvolvimento estadual, caracterizando a importância econômica do Espírito Santo em todo o território nacional e, quiçá, no mundo.

Desta forma, em Vitória, durante o período de 1970 a 2000, formou-se um conjunto de alterações de ordem econômica, que abriram um enorme mercado de trabalho na cidade. Além disso, as novas atividades econômicas atraíram para a cidade enorme população rural capixaba e um formidável contingente de migrantes de outras localidades do país, o que contribuiu para descaracterizar socialmente a Grande Vitória.

Se até a década de 1950, o ramo de serviços ainda era pouco diversificado, a partir dos anos de 1970 muitas mulheres foram inseridas nas atividades consideradas femininas, seja nas empresas que se abriam, seja nos setores relacionados à cultura, às finanças, ou mesmo à administração pública, embora se lhe exigissem um nível educacional mais aprimorado. Desta forma, muito lentamente as mulheres começaram a sobressair-se na educação e em profissões rentáveis, mesmo assim em número bastante reduzido, pois, embora a população feminina reagisse aos estereótipos e à segregação profissional, muitos preconceitos insistiam em permanecer.

A grande massa populacional feminina, que precisava trabalhar para sustentar sozinha ou mesmo contribuir para o sustento de sua família, não estudou ou não prolongou seus estudos para além dos primeiros anos de escola. Ainda assim, foi incorporada no mercado de trabalho, como assalariada ou não. Milhares de mulheres sem a qualificação exigida pelas atividades industriais e comerciais urbanas ligaram-se a atividades informais, tornando-se biscateiras e vendedoras ambulantes ao redor do centro urbano de Vitória. Descontando as que desenvolviam atividades na área de magistério, o número absoluto delas no mercado de trabalho era muito pequeno. 
Contudo, destaca-se que todo processo de crescimento econômico capixaba trouxe reflexos para a sociedade vitoriense, que perdeu o tradicional perfil de cidade colonial, tornando-se um aglomerado urbano que absorveu enorme quantidade de pessoas vindas do mundo rural em busca de empregos. A capital capixaba sofreu um impacto populacional e congestionou-se com a expansão de favelas e atividades informais. Ao mesmo tempo, formava-se um novo mercado, secundário e terciário, promovido pela expansão do parque industrial. Essas alterações influenciaram significativamente a vida da mulher vitoriense sob inúmeros aspectos.

Em 1970, da população total de 70.103 mulheres habitantes de Vitória, somente $35,57 \%$ estavam no mercado de trabalho. Mas, foi o comércio e o setor de serviços que abriram maiores oportunidades de trabalho para as mulheres. Em 1980, o setor terciário ocupava $41,15 \%$ de todos os empregos disponíveis na cidade e dentro deles enquadravam-se $53,74 \%$ da população feminina economicamente ativa. Os empregos nesse setor assumiram um papel relevante dentro do mercado empregatício feminino, principalmente nas atividades da área de serviços, que em dez anos teve um crescimento na ordem de 48,59\%. Esse fenômeno se explica pelo crescimento populacional de Vitória. No Censo de 1980, a população economicamente ativa que vivia ao redor da cidade, isto é, na área da Grande Vitória, era composta de 532.079 pessoas, sendo $51,15 \%$ mulheres.

Nessaépoca, os empregosqueabsorviama mão-de-obrafeminina se multiplicaram em relação à década anterior. Porém, as mulheres em geral ainda permaneciam desenvolvendo atividades que thes proporcionavam uma baixa remuneração. Sua presença no mercado de trabalho era maciça e, de certa forma, ainda enfrentavam barreiras: ocupavam os lugares menos privilegiados e suas condições de trabalho eram mais precárias do que as dos homens. (BRUSCHINI, 1999) 
As trabalhadoras que não conseguiam emprego recorriam à estratégia de sobrevivência em um mercado que não mantinha ligações com o setor formal de trabalho, vinculando-se à prestação de serviços não especializados ou explorando pequenos negócios e criando um grande mercado informal.

Em fins dos anos de 1980, o mercado de trabalho secundário fez surgir novas oportunidades de trabalho para as mulheres de Vitória. Nessa época, a participação feminina no mercado capixaba chegou a atingir a casa dos $53,23 \%$ do total da população ativa da cidade. 0 setor de indústria abriu vagas para a mão-de-obra feminina que cresceu $60,21 \%$ entre os anos de 1980 a 1991. Destacaram-se a indústria de construção civil, que empregou 644 mulheres em atividades consideradas eminentemente masculinas, tais como pedreiras, encarregadas de obras, pintoras, dentre outras, e a de indústria de transformação, que, sozinha, abriu espaço para 2.685 mulheres, aumentando suas vagas em torno de $48,64 \%$, durante esse período.

É importante mencionar o fato de que no âmbito dessas ofertas de trabalho, ocorreram significativas participações femininas no mercado que as estatísticas não conseguem captar, pois as dificuldades para se registrarem todas as atividades desenvolvidas por elas são expressivas. Não se leva em conta, até hoje, por exemplo, a realização das tarefas realizadas dentro de casa, por não serem consideradas como trabalho produtivo, apesar das mulheres seguirem sendo as principais responsáveis pelas atividades desenvolvidas no espaço doméstico e pelo cuidado com os filhos e demais familiares. Independente do fato de estar ou não no mercado de trabalho, as mulheres que realizam tarefas dentro de suas casas são desvalorizadas e suas atividades não são computadas nas estatísticas, que as classificam como "inativas" ou "domésticas".

Se todas as mulheres que se casam e trabalham dentro de seu domicílio fossem consideradas, não apenas como "esposa", mas também 
como trabalhadoras economicamente ativas, as taxas globais de atividade feminina seriam consideradas superiores às existentes e, desse modo, atingiriam um índice aproximado de 99\%. (BRUSCHINI, 1999)

Tal perspectiva torna evidente a desconsideração pelo trabalho doméstico realizado pela mulher e contribui para a manutenção da hierarquia entre os gêneros, além de confirmar a preservação da característica feminina criada pela sociedade, que ainda identifica a mulher como "esposa".

Na verdade, a compreensão desse fenômeno se dá pela própria interpretação que a historiografia e a literatura realizaram da tutela que o homem exercia sobre a mulher, tutela essa, diretamente relacionada à ordem econômica e ao controle político da sociedade. Na primeira, pela dependência econômica feminina para com o homem e a rígida divisão social do trabalho e, no segundo, pela manutenção da supremacia masculina na sociedade.

Com base nesses interesses, ao longo dos séculos, a relação da vida feminina com o casamento se estreitou, fazendo com que milhares de gerações acreditassem que esse fosse o único "sonho das mulheres".

\section{A MULHER TRABALHADORA E O CASAMENTO}

Para as mulheres, o crescimento econômico capixaba criou perspectivas que desafiaram e romperam os costumes patriarcais que, ainda no início dos anos de 1970, persistiam em Vitória. As gerações anteriores que, com muito custo, redefiniram práticas comuns às suas ascendentes, abriram novas perspectivas de mudanças de comportamento para as gerações futuras: acorreram à educação, profissionalizaram-se, deixaram de lado a tradição de se casarem com a idade socialmente considerada ideal e praticaram o direito do rompimento conjugal. 
A mudança no entendimento do trabalho feminino não só descaracterizou as tradicionais atividades femininas domésticas como também promoveu alterações significativas em seu perfil: as filhas das mulheres que entraram no mercado de trabalho nos anos de 1970 eram adolescentes naquela época e defrontavam-se com um mundo repleto de possibilidades e diferentes estilos de vida, que alteravam profundamente o comportamento feminino das gerações seguintes. Suas aspirações provocaram mudanças decisivas na estrutura da sociedade capixaba, indicando que a presença feminina modificaria definitivamente a estrutura do mercado de trabalho.

Até mesmo porque, em Vitória, desde os anos de 1960, instituições como o Serviço Social da Indústria (SESI) e o Serviço Nacional do Comércio (SENAC), mantinham diversos cursos de corte e costura, e também algumas entidades religiosas e comunidades de bairro ofereciam cursos de treinamento para bordadeira, cabeleireira, costureira, cozinheira, manicure e doceira para mulheres de classe popular que pretendem adquirir uma profissão.

Na realidade, a mudança no entendimento do trabalho feminino não só descaracterizou as tradicionais atividades femininas domésticas como também promoveu alterações significativas em seu perfil: as filhas das mulheres que entraram no mercado de trabalho nos anos de 1970 eram adolescentes naquela época e defrontavam-se com um mundo repleto de possibilidades e diferentes estilos de vida, que alteravam profundamente o comportamento feminino das gerações seguintes. Suas aspirações provocaram mudanças decisivas na estrutura da sociedade capixaba, indicando que a presença feminina modificaria definitivamente a estrutura do mercado de trabalho.

As atividades femininas, dentre os anos de 1970 a 2000, não somente proporcionou um aumento da participação das mulheres no mercado de trabalho capixaba, mas também fez com que o mercado 
absorvesse uma mão-de-obra feminina mais qualificada. As mulheres cujas mães antes se classificaram como profissionais de serviços considerados tipicamente femininos deixaram de se auto-relacionar como tal e fizeram a opção por um preparo profissional, mesmo que isso exigisse muitos anos de estudos.

Somente a partir dos anos de 1980, na expectativa de atender ao mercado que se firmava em Vitória, outras profissões foram sobressaindose em detrimento da profissão doméstica. Nessas ocupações, a participação feminina era maior na burocracia. Havia, também, forte tendência ao aumento do trabalho feminino entre os profissionais liberais.

Nos anos de 1990, o processo de feminização do mercado capixaba entrou em franca ascensão. Assim como nos serviços de administração empresarial, de contabilidade, de comunicação, de tecnologia, de informática e de assistência social, as mulheres aumentaram sua participação em empresas que atuavam no ramo de turismo, de comércio exterior e de escolas de formação profissional - em níveis de graduação e pós-graduação. Nessa época, muitas mulheres competiram em condições de igualdade de conhecimentos com os homens e superaram as barreiras que insistiam em existir no mercado de trabalho, e chama atenção a tendência à ocupação feminina em cargos executivos, nas posições de comando das empresas, como presidente, gerente-geral ou função equivalente.

Considerando a presença feminina em todos os níveis hierárquicos, em fins do período pesquisado, mais precisamente entre os anos de 1999 e 2000, constatou-se que houve um grande crescimento da presença feminina em altas posições, principalmente como encarregadas e coordenadoras. A concentração delas em cargos de assistentes e em posições de atendimento demonstra que as mulheres são vistas como mais aptas para o trato com clientes. 
Disso se conclui que a qualificação profissional se tornou um aspecto fundamentalmente significativo na vida das mulheres. E na medida em que elas galgaram a escala produtiva, permitiram-se adquirir maiores oportunidades de trabalho no mercado, o qual progrediu com a produção de bens materiais e permitiu, sobretudo, que elas adquirissem uma liberdade estrutural na sociedade, principalmente na sociedade familiar.

Desta forma, pode-se inferir que depois que as mulheres emprestaram sua mão-de-obra para contribuir na manutenção financeira da família, deixaram de ser consideradas simplesmente seres passivos de reprodução, mostrando capacidade em gerir seu próprio sustento e o de sua família. Foi essa transformação no status econômico feminino que caracterizou a mudança das relações femininas com o casamento.

Se antes havia a importância do casamento, agora, as mudanças econômicas das mulheres podem ser identificadas como paradigmas de alterações no comportamento feminino, antes dedicado, por influência secular, como visto inicio deste ensaio, ao casamento. Concretamente, dentre essas mudanças, destaca-se aquela verificada nas estatísticas da união consensual. No Censo Demográfico de 1970, a união do casal sem registro civil ou religioso já era computada como união consensual e, no Espírito Santo, esse estado conjugal representava 3,73\% do total de mulheres casadas. Só na cidade de Vitória, capital do Estado do Espírito Santo, esse percentual chegou a representar $3,80 \%$ das mulheres recenseadas que se declararam casadas. (FIBGE, Censo Demográfico do Espírito Santo, 1970)

No censo de 1980, (FIBGE. Censo Demográfico do Espírito Santo, 1980) a Fundação Instituto Brasileiro de Geografia e Estatística (FIBGE), ao investigar o estado conjugal da população capixaba, não levou em conta elementos que permitiriam o conhecimento do estado civil de mulheres que viviam com seus parceiros, informando apenas que $10,37 \%$ das mulheres do Estado viviam em outra situação conjugal que não a de casadas no civil e no 
religioso. O Anuário Estatístico do Espírito Santo de 1980/1985, (ESPÍRITO SANTO (Estado). 1986), no entanto, informa que, em Vitória, o percentual de mulheres vivendo uma união conjugal sem registro em cartório, entre 1970 e 1980, aumentou em torno de 60,9\%, ou seja, em números absolutos, no ano de 1970, 1.689 mulheres declararam viver em uniões conjugais consensuais e, em 1980, o número aumentou para 4.504 .

De modo geral, foi na década de 1980 que houve o maior número de casamentos, com uma incidência maior no ano de 1987 (2.783). Dois fenômenos chamam atenção para esse fato: o primeiro, por se tratar do ano em que se comemoravam dez anos da promulgação da Lei n. ${ }^{\circ} 6.515$, de 17 de dezembro de 1977, que instituía o divórcio no Brasil, e o segundo, por esse número aparecer no topo da pirâmide que retrata a evolução dos casamentos em Vitória.

Muitas mulheres desistiram mesmo de casar, preferindo morar com o companheiro sem precisar assinar nenhum documento perante a Justiça Oficial ou a Igreja. Alteraram completamente as tradições que as levavam ao altar virgens e com pouca idade. Socializadas para serem esposas e mães, foram também estimuladas a estudar e a aspirar à autonomia e à igualdade, deixando de lado o casamento como única alternativa de seu destino e, em meio a um mundo de possibilidades, não se acanharam diante do rompimento conjugal.

Concretamente, o enfraquecimento da importância do casamento na vida feminina pode ser visto quando o comportamento feminino a tal instituição sofreu mudanças progressivas: aumentou o número de uniões consensuais, os casamentos religiosos perderam sua importância, houve uma queda quantitativa de casamentos oficiais, aumentou consideravelmente o número de separações e divórcios, além de as mulheres se casarem cada vez com mais idade. 
CONSIDERAÇÕES FINAIS

A crença de que a mulher nasceu para tornar-se mãe e esposa, via casamento, obteve êxito durante séculos e, no Brasil, a sociedade ideologicamente constituída sob o signo do patriarcalismo, a tomou como verdadeira, considerando-a como pertencente à natureza feminina. Principalmente, porque em tal sociedade as mulheres não trocavam sua lida por salários e dependiam economicamente dos homens.

Somente quando as mulheres foram se inserindo no mercado de trabalho e romperam com tais amarras financeiras, puderam mudar sua forma de pensar e sentir o casamento, levando toda sociedade a um novo entendimento no que diz respeito a relação mulher e casamento.

Procurando observar como se deu tal mudança de pensamento, pretendeu-se reforçar esse entendimento, primeiramente com o estudo dessa relação que nasceu nos primórdios da sociedade humana, no qual se observou como a vida feminina foi sendo atrelada à instituição que, por longos séculos privou a mulher de crescer intelectual e profissionalmente. Em um segundo momento, buscou-se, por meio de dados históricos observar como o mercado de trabalho absorveu a mão de obra feminina e o quanto essa dinâmica transformou a vida da mulher, e por tabela, de toda a sociedade.

Por fim, foi realizada uma pesquisa com dez mulheres, moradoras da cidade de Vitória, que iniciaram sua vida profissional, mantiveram um casamento, seja oficial ou não, e passaram pelas mudanças econômicas e sociais dos anos de 1980 e 1989, e pelo processo de rompimento conjugal. Foram feitas entrevistas com o intuito de observar detidamente o modo como algumas das mulheres que viveram a transformações nas suas vidas percebiam questões que relacionavam a vida feminina ao casamento e que, com sua inserção no mercado de trabalho, poderiam mostrar como ocorreu a mudança na relação mulher e casamento. 
A exposição de detalhes de vidas dessas mulheres e do que pensavam a respeito de sua relação com o casamento e o trabalho revelou-se bastante profícua, na medida em que as experiências pessoais apontavam para a possibilidade de vislumbrar na história local versões mantidas por um segmento populacional: mulheres profissionais separadas e/ou divorciadas. Além desse critério, também serviram como parâmetros o fato de o início da vida profissional dessas mulheres ter ocorrido na cidade de Vitória, e o de terem se unido a um homem de forma conjugal após 1970 e se separado e/ou divorciado antes de 2000. Esses foram os únicos critérios previamente adotados.

Do grupo das contatadas para as entrevistas, algumas eram de meu conhecimento pessoal, as quais, ao tomarem conhecimento das exigências estabelecidas para a participação na pesquisa, se mobilizaram e contribuíram comigo, indicando outras mulheres que podiam e queriam ser entrevistadas.

Cada entrevista durou cerca de duas horas. Antes de iniciá-la, para deixar as entrevistadas bem à vontade, foi-Ihes explicado de forma minuciosa os objetivos da pesquisa e como se pretendia expor sua visão a respeito da relação mulher, casamento e trabalho, além de comunicar-lhes que não usaria seus nomes originais.

Considerando ser a liberdade de exposição a verdadeira razão da pesquisa, procurou-se não impor uma ordem rígida às questões. Ao mesmo tempo, foram feitas perguntas de forma ampla, sempre colocadas em grandes blocos. A adoção de um roteiro de entrevistas conferiu uma dinâmica entre entrevistadora e entrevistada, o que possibilitou a obtenção de dados qualitativos ao mesmo tempo em que facilitou a comparabilidade do material coletado. Segundo Meihy (1996), esse é o tipo de entrevista que estimula a relação com a população entrevistada, dando vazão à fluidez de informações notáveis e autênticas que contribuem muito para o conhecimento de um 
fenômeno, neste caso a História das Mulheres. É a partir desse roteiro que os dados serão apresentados.

As entrevistadas Paula, Mônica e Adriana são originárias de famílias vindas do interior do Estado do Espírito Santo. De outros estados, notadamente de Minas Gerais e Rio de Janeiro, vieram Elizabeth, Maria de Fátima e Eliane. Todas, à exceção de Eliane, que já tinha 23 anos quando se estabeleceu em Vitória, foram levadas por seus pais, nas décadas de 1960 e 1970, antes de completarem 14 anos de idade.

Nascidas em famílias classificadas por elas próprias como de classe média e pobre, essas mulheres foram para Vitória acompanhando os pais, que buscavam emprego e uma vida melhor no mercado que se abria com a implementação dos Grandes projetos Industriais. Paula era filha de pais lavradores, analfabetos e pobres. Elizabeth era filha de um motorista e uma doméstica, pobres, que não completaram o ensino fundamental. Mônica era filha de uma doméstica analfabeta e de um lavrador que tentou a sorte como frentista, no interior do Espírito Santo, mas não conseguiu sustentar a família com o que ganhava. Somente Adriana, Eliane e Maria de Fátima vieram para Vitória em situação financeira melhor, uma vez que seus pais eram, respectivamente, comerciante, fazendeiro e fiscal de renda.

Glória, Ana e Ângela nasceram em Vitória, mas também afirmaram ser originárias de famílias pobres. Diferente das demais, Helena, que também havia nascido em Vitória, no seio de uma família de classe média, afirmou que durante os anos de 1970 seus pais sofreram um abalo financeiro que fez mudar sua situação social.

Mesmo aquelas que foram para Vitória ainda crianças viveram nessa cidade a maior parte de sua vida, lá estudando e se formando. À exceção de Eliane que, do ensino fundamental ao superior, estudou somente em escola particular, no interior de Minas Gerais, todas estudaram em 
escolas públicas de Vitória. Ângela, Ana, Glória e Helena estudaram também em escolas particulares.

Das dez mulheres, Paula foi a única que não concluiu o ensino fundamental. Mônica abandonou o ensino médio antes de completar o primeiro ano. Nesse nível de ensino, Glória fez o curso Técnico em Contabilidade, Adriana, o curso Técnico em Agrimensura, Ângela, o curso Técnico em Estradas e Ana, o curso Técnico em Secretariado. Somente Eliane e Elizabeth cursaram o secundário Científico, preparatório para o ensino superior. Maria de Fátima e Helena fizeram o curso Normal, que as preparou para o magistério.

Quase todas as entrevistadas concluíram o curso superior. Eliane formou-se em Odontologia e trabalha em seu próprio consultório. Maria de Fátima fez o curso de Direito e já foi proprietária de um cartório de Registro Civil. Glória formou-se em Administração de Empresas e atuou em empresa administradora de condomínios. Ana, Ângela, Helena, Adriana e Elizabeth optaram por cursos que preparam para o magistério na área de Ciências Humanas. Dessas, as quatro primeiras atuam hoje em várias escolas de ensino superior de Vitória, e Elizabeth trabalha em uma escola particular, onde ministra aulas para o ensino médio e o pré-vestibular.

Ana, Ângela, Helena, Adriana, Elizabeth e Eliane fizeram cursos de pós-graduação no Brasil ou no exterior.

Apesar de a maioria das entrevistadas ter um grau de instrução elevado para os padrões brasileiros, a cultura, que por séculos foi utilizada para incutir o entendimento de que o destino feminino era o casamento, as convenceu a adotar a ideologia das concepções teóricas que pregavam o ideal de comportamento feminino voltado para o casamento, ainda nos anos de 1970. Literatura, cinema, novelas e propagandas foram meios descritos por Mônica, Adriana, Ana, Ângela e Helena como os que transmitiam à 
sociedade a idéia de que a natureza feminina as conduzia ao casamento e à maternidade.

Adriana, Ângela e Ana confirmaram terem lido muitas revistas e gostado de novelas que mostravam a importância do casamento na vida das mulheres. Elas acreditam que tanto as revistas quanto as novelas da televisão influenciam até hoje nas decisões femininas a respeito do casamento. Formadores de opinião, esses instrumentos, na opinião dessas entrevistadas, induzem as mulheres a serem boas donas-de-casa e, de certa forma, submissas aos seus maridos, além de levantarem a bandeira de que elas deveriam ser preparadas para o casamento desde pequenas.

Maria de Fátima, Eliane e Glória acham que as revistas femininas, a televisão e a família não exerceram qualquer influência na sua concepção sobre o casamento. Elas consideram que não foram educadas para isso e não houve qualquer interferência externa quando resolveram se casar. Contrariando essa posição, Elizabeth e as outras mulheres afirmaram terem sido educadas para o casamento, além de receberem influência de amigas da faculdade, tias, primas e avó paterna.

Educadas ou não para o casamento, Glória se casou aos 17 anos, Mônica, aos 18 anos, Ângela e Elizabeth, aos 19 anos de idade. Maria de Fátima e Ana casaram-se com 20 anos, Paula, com 22, Eliane, com 24 e Adriana, com 28 anos. Somente Helena, que teve uma união não oficializada, começou sua vida conjugal aos 31 anos de idade, com um homem mais novo do que ela.

As que se casaram na década de 1970 foram Glória, em 1971, Maria de Fátima, em 1976, Ana, em 1977, e Elizabeth, em 1979. Todas se casaram na Igreja e no cartório.

Na década de 1980, como visto anteriormente ocorreu o maior número dos casamentos na cidade, de acordo com o levantamento efetuado nos cartórios de Registro Civil, nos recenseamentos e também com as 
entrevistadas. Ângela casou-se em 1980, Eliane, em 1981, Helena, em 1983, e Mônica e Paula, em 1987. Paula e Eliane se casaram no religioso e no cartório. Mônica e Ângela oficializaram suas uniões no cartório, mas não quiseram ou puderam casar-se na Igreja. Helena optou pela união consensual em 1983.

Adriana foi a única mulher pesquisada a se casar na década de 1990. Casou-se aos 28 anos, na Igreja Católica e no cartório.

Quase todas elas, quando iniciaram sua vida conjugal, acreditavam que era esse o seu destino. Elizabeth desde muito cedo recebeu uma educação que a levou a se casar aos 19 anos, acreditando que "fosse ficar casada pelo resto da vida". Foi criada no interior de uma família religiosa e se casou com o primeiro namorado "sério" que teve.

Paula, que também recebeu uma educação religiosa e voltada para o casamento, disse que se casou aos 22 anos com a expectativa de que "seria feliz e iria compartilhar de coisas boas com o marido pelo resto da vida". Ana, aos 20 anos, acreditava que o seu casamento era a "coisa mais importante da vida", uma vez que realizava o seu sonho. No fundo, essas mulheres adentraram ao casamento com a esperança de que estavam realizando sua missão feminina na sociedade.

Desejando "Viver feliz a vida toda", "Ficar com o homem que eu amo por toda vida", "Fazer tudo para agradar ao homem que amo" e "Viver em um mar de rosas, num paraíso eterno", Paula, Ana, Mônica e Helena afirmaram que realizaram suas expectativas. Maria de Fátima disse que no início do casamento todos os seus desejos foram alcançados, mas depois que teve seus filhos "tudo mudou".

Nascidas nos idos de 1950 e 1960, quando as mulheres capixabas ainda eram educadas para seguir um comportamento considerado apropriado para seu gênero, as entrevistadas não ficaram isentas de atitudes ambíguas e cheias de contradições. Independente da condição financeira de suas famílias, foram preparadas para o desempenho de tarefas no lar, ao mesmo 
tempo que cursavam uma escola profissionalizante e buscavam um espaço no mercado de trabalho. Aprenderam a exercer atividades remuneradas fora de casa como algo imprescindível na manutenção econômica da casa, assim como a defender sua família como seu domínio natural.

Parece que, pelo menos Eliane, Maria de Fátima, Helena e Mônica interiorizaram bem essas contradições, pois concordaram que as mulheres foram talhadas para o amor e o casamento. Helena, Maria de Fátima, Mônica, Paula e Adriana acham que "todas as mulheres devem se casar, para saberem como é."

Contudo, os elementos contritos presentes em suas falas chocam-se com a ideologia do casamento por amor. Mônica queria casar-se para "ficar livre da pressão" que sua mãe fazia sobre ela, quando Ihe dizia o que fazer de sua vida. Para ela, o casamento seria o "lugar" onde faria o que quisesse, da forma que melhor the aprouvesse. Casou-se "pensando que ficaria livre". Eliane afirmou que "tinha dificuldades de relacionamento com o pai" e queria casar-se para "ter uma família que gostaria de ter tido desde criança".

Aos olhos de Mônica e Eliane, embora o casamento fosse o objetivo de sua vida, representava uma fuga aos problemas de relacionamento enfrentados em suas famílias de origem. Por outro lado, suas falas denotam, de certa forma, que existia um grande envolvimento com a família, mesmo que muitas vezes fosse negativo.

Maria de Fátima demonstrou ressentimento em relação ao pai, principalmente no tocante à pressão que ele exercia sobre ela para que se casasse logo. Ela revelou que só pôde ir ao cinema com o namorado aos 15 anos de idade, depois que ficaram noivos, e que seu pai a obrigara a se casar aos 18 anos. Ela então terminou o noivado. Revelando-se contrária à idéia de que deveria casar-se somente porque seu pai exigia, preferiu continuar seus 
estudos e trabalhar. Casou-se algum tempo depois, com um homem que ela mesmo escolheu.

Envolvidas diretamente com suas mães, estas quase todas donas de casa e com pouco estudo, as mulheres entrevistadas manifestaram querer viver de forma diferente. Mesmo as que não conseguiram prolongar seus estudos de modo a se tornar profissionais de alto gabarito e conseguir um trabalho que lhes desse uma boa remuneração, começaram a buscar um trabalho capaz de promover sua independência econômica desde muito cedo.

Mônica, aos 10 anos de idade, começou a trabalhar como doméstica, fora da casa de seus pais. Paula, aos 15 anos, era doméstica em casa de uma família "rica". Maria de Fátima, aos 13 anos, ajudava sua mãe no cartório e recebia uma remuneração que a fazia sentir-se "poderosa". Ana, tão logo completou 14 anos, "conseguiu emprego de atendente em uma empresa de representação de material escolar". Aos 15 anos, Ângela trabalhava como secretária em um escritório de vendas. Adriana, aos 17 anos, fazia estágio numa firma que atuava no ramo de aerofotogrametria. Glória começou a trabalhar no comércio antes de completar 16 anos. Helena, aos 15 anos, começou o curso secundário de magistério e iniciou sua trajetória de alfabetizadora, em uma escola pública onde sua tia trabalhava. Somente Eliane e Elizabeth começaram a trabalhar após completarem 23 e 22 anos, respectivamente, a primeira, em uma clínica odontológica, e a segunda, como professora, em uma escola pública.

Depois de casadas, somente Paula parou por um tempo de exercer atividades extradomésticas. Mesmo depois que tiveram filhos, as mulheres continuaram a trabalhar fora de casa. Elas precisavam contribuir para o sustento da família ou "para continuar a ser dona de meu nariz", conforme afirmou Ana. Algumas se mantiveram no mesmo ramo do início 
de suas trajetórias profissionais, outras mudaram não só de emprego, mas também de profissão.

Eliane foi a única mulher a receber um salário maior do que o do marido desde que se uniram. Por causa disso, alegou que ele tinha "ciúmes" de suas atividades profissionais, demonstrando que não gostava que ela "fizesse cursos de atualização". No período em que estiveram casadas, somente Helena conseguiu ganhar mais do que seu companheiro. As outras mulheres pesquisadas não conseguiram receber um salário que superasse o de seu cônjuge.

Glória, Maria de Fátima, Ângela e Elizabeth afirmaram que seus maridos eram indiferentes às suas atividades extradomésticas e não se preocupavam quando saíam para o trabalho. Maria de Fátima afirmou que "ele até gostava, pois sabia que eu estava ganhando dinheiro e porque podia ficar mais tempo a sós com a empregada".

Por seu turno, Adriana disse que a relação de seu cônjuge com seu trabalho era "ambígua", uma vez que, "ao mesmo tempo em que ele tinha respeito, ele tinha ciúmes. Era como se eu estivesse roubando o tempo em que deveria me dedicar a ele". Já o marido de Mônica costumava ficar vigiando para ver o que ela fazia quando saía do trabalho. Segundo ela, ele demonstrava insegurança em relação às suas atividades extradomésticas e ambos brigavam muito por causa disso.

Interessante foi o relato feito por Helena: "Quando ele ganhava mais do que eu, a relação dele com o meu trabalho de professora era ótima. Ele elogiava o que eu fazia e me ajudava em minhas tarefas quando eu fazia pós-graduação. Mas quando eu comecei a ganhar mais e bancar uma série de coisas dentro de casa, ele começou a implicar comigo. Não com o meu trabalho, mas comigo. Piorou quando ele ficou desempregado. Tudo o que antes ele elogiava em mim, passou a ser visto como algo negativo. Ele criticava meu cabelo, que antes achava lindo, até meu modo de falar e de 
andar. A implicância dele, ou mesmo ciúme ou inveja, com o meu trabalho, foi transportada para mim".

Mesmo não relacionando seus trabalhos extradomésticos com o fim de seus casamentos, todas as mulheres deixaram claro que, se não desenvolvessem alguma atividade remunerada durante o período da união conjugal, não teriam conseguido desvencilhar-se do "inferno" em que se tornou a convivência com seu cônjuge.

Paula alegou que, quando chegava do trabalho, além de fazer as tarefas domésticas, ainda tinha que esperar por seu marido que "começou a ficar fora de casa muitos dias". Ele trabalhava em uma fábrica de sandálias na Grande Vitória e não voltava para casa no fim do expediente. Ela separou-se aos 33 anos de idade, depois de 11 anos de convivência. Não registrou sua separação no cartório, e seu marido foi viver com outra mulher. Com sua experiência, não quer mais saber de casamento. Hoje, só "namora".

Maria de Fátima estava grávida de seu segundo filho quando, chegando a casa para almoçar, flagrou seu marido na cama com a empregada. Dias depois, sua filha de seis anos encontrou o pai novamente com a empregada. Separou-se e divorciou-se depois de 9 anos de casada. Registrou o rompimento conjugal no Cartório Zilma Leite, o mesmo cartório onde registrou seu segundo casamento.

Helena afirmou que sua relação conjugal era muito feliz e jamais Ihe passou pela cabeça que seu companheiro pudesse estar namorando outra mulher, até o dia em que descobriu, 12 anos após o início da união, que ele tinha outra. "Coloquei-o para fora de casa e, como não havia registrado o casamento em nenhum cartório, tudo foi mais fácil", alegou. Sofreu muito e afirmou não querer mais unir-se a nenhum homem. Continuou trabalhando e estudando, no Brasil e na Europa.

O mesmo aconteceu com Elizabeth. Seu marido confessouIhe estar apaixonado por outra mulher. Ela estava grávida, mas mesmo 
assim optou pelo rompimento conjugal, depois de 2 anos de casamento e 6 de namoro. Contudo, alegou que se casaria outra vez, porque acredita poder ser feliz "numa relação a dois". Hoje, seu trabalho a remunera em aproximadamente 15 salários e é proprietária de quatro imóveis.

"Foi uma discussão boba, mas a forma grosseira como ele se dirigiu a mim, dentro de minha casa, foi o suficiente para iniciar o fim de meu casamento." Adriana, a partir daí, não mais conseguiu conviver com seu marido. Passaram a brigar constantemente. Saiu de casa e deixou-lhe todos os bens adquiridos durante o casamento, que durou 4 anos. Acredita que seu trabalho, que lhe rende em torno de 20 salários, foi um forte aliado para sua decisão. Atualmente vive uma união estável e tem um filho dessa união.

Brigas e discussões também se tornaram rotina no relacionamento de Mônica e seu marido. Mas seu casamento terminou no dia em que ele bateu nela. Ficou casada por 9 anos, teve dois filhos e separou-se aos 27 anos de idade. Não registrou sua separação em nenhum cartório de Vitória e vive hoje uma união consensual. Continua a trabalhar como doméstica e percebe em torno de 1 salário mínimo e meio.

"Meu casamento acabou na lua-de-mel, quando tivemos uma grande discussão", disse Ana. Mesmo assim, conviveu com o marido por mais 8 anos. Teve uma filha e separou-se aos 29 anos de idade. Não se casou novamente, mas também não realizou seu sonho "de se tornar proprietária de uma escola de ensino superior". Continuou a dar aulas em uma faculdade próxima de Vitória e percebe em torno de 12 salários.

"Casei com a intenção de viver feliz até o fim de minha vida, mas não deu", disse Glória. Ficou casada por 4 anos e alegou não se lembrar da causa específica de sua separação, "pois já faz muito tempo que isso aconteceu". Teve um filho desse casamento e outro de uma união estável, que também acabou. É administradora de condomínios da orla marítima de 
Vitória e Vila Velha, ganha em torno de 15 salários mínimos e não quer mais se "envolver com ninguém".

Ângela, mãe de uma menina, terminou seu casamento "quando ele se sentiu muito rico" e não precisou mais dela. Casada por 10 anos, disse que sempre trabalhou para ajudar seu marido nas despesas da casa. Contudo, ele conseguiu "subir na vida" e passou a ganhar muito dinheiro, "me desprezando". Ela conheceu outra pessoa e pediu a separação. Foi morar com seu novo parceiro, com quem tem dois filhos.

O casamento que durou mais tempo foi o de Eliane, 17 anos. Mas, já no primeiro ano, "eu abri mão de ser eu", disse ela. "Ele era agressivo, gritava comigo, ao ponto de eu precisar fazer terapia." Apesar disso, teve dois filhos, continuou estudando e montou seu próprio negócio. Separouse e divorciou-se. Hoje convive consensualmente com outro homem, ganha mais de 20 salários e só quer usufruir o que já conquistou. Contudo, expressa seu desejo de continuar estudando e trabalhando: "Quero fazer cursos de especialização e não quero parar no tempo."

Todas as mulheres conseguiram, cada uma a seu modo, conquistar um lugar no mercado de trabalho e não depender economicamente de seus maridos. Elas alegaram estar ganhando o suficiente para se sustentar e à sua família, sem precisar de pensão alimentícia nem de outro marido para sustentá-las. $O$ trabalho extradoméstico que realizam essas mulheres, mesmo que algumas o encarem como "obrigação" e "necessidade", as $\underline{\text { faz }}$ sentirem-se cidadãs, uma vez que o encaram como o "complemento da vida".

O cotejo dos dados levantados na documentação da Fundação Instituto Brasileiro de Geografia e Estatística e nas entrevistas com as mulheres possibilitou ampliar as representações a respeito das relações entre a mulher e o casamento. Embora se não tenha a pretensão de que este trabalho represente fidedignamente todos os elementos complexos que compõem essa problemática, as reflexões expostas aqui, de certa forma, 
contribuem para o esclarecimento das interrogações que originaram este trabalho.

Os resultados obtidos podem ser relacionados às mudanças de comportamento das mulheres que se inseriram no mercado de trabalho e se casaram. O fato de não mais dependerem economicamente de seus pais ou maridos possibilitou a elas independência financeira, o que contribuiu para a modificação dos padrões de comportamento que lhes foram impostos durante séculos e também para a criação de novos paradigmas na relação mulher e casamento, uma vez que as mulheres não mais o encaram como único destino, nem como eterno.

\section{REFERÊNCIAS}

ALBORNOZ, Suzana. O que é trabalho. São Paulo: Brasiliense, [1986]. p. 1168. (Coleção Primeiros Passos, v. 13).

BADINTER, Elisabeth. Um amor conquistado: o mito do amor materno. Rio de Janeiro: Nova Fronteira, 1985.

BARROSO, Carmem \& COSTA, Albertina Oliveira (org.) Mulher. Mulheres. São Paulo:Cortez;Fundação Carlos Chagas, 1983.

BASSANEZI, Carla. Virando as páginas, revendo as mulheres: revistas femininas e relações homem-mulher. 1945-1964. Rio de Janeiro: Civilização Brasileira, 1996.

BITTENCOURT, Gabriel. Café e modernização: o Espírito Santo no século XIX. Rio de Janeiro: Catedra, 1987.

BROWN, Peter. Corpo e sociedade: o homem, a mulher e a renúncia sexual no início do cristianismo. Rio de Janeiro: Zahar, 1990.

BRUSCHINI, Cristina. Mudanças e Persistência no Trabalho Feminino (Brasil, 1985 a 1995). In: SAMARA, Eni de Mesquita. (org.) Trabalho Feminino e Cidadania. São Paulo: Humanitas/FFLCH/USP, 1999. P. 29-55.

CIRIBELLI, Marilda Corrêa. Reflexões sobre a história da mulher em Roma. Phoînix, Rio de Janeiro, ano 2, p. 137-146, 1995.

Hist. R., Goiânia, v. 19, n. 3, 2014 
DAVIDSON, N. S. A Contra-Reforma. São Paulo: Martins Fontes, 1991.

DEL PRIORE, Mary. Corpo a corpo com a mulher: pequena das transformações do corpo feminino no Brasil. São Paulo, SENAC, 2000.

DELUMEAU, Jean. A civilização do Renascimento. Lisboa: Estampa, 1983. v. 1. ENGELS, Friederich. As origens da família, da propriedade privada e do estado. 11. ed. Rio de Janeiro: Civilização Brasileira, 1987.

FRANCO, Sebastião Pimentel e SÁ, Nicanor Palhares. Gênero, etnia e movimentos sociais na História da educação. Vitória: Edufes, 2011.

HIPONA, Agostinho. A Cidade de Deus. Parte 1 e 2. Petrópolis: Vozes, 1990.

KÜHNER, Maria Helena. $O$ desafio atual da mulher. Rio de Janeiro: Francisco Alves, 1977.

MAFFRE, Jean-Jacques. A Vida na Grécia Clássica. Rio de Janeiro: Zahar, 1989.

MARCHESINI JÚNIOR, Waterloo. Instituição do divórcio no Brasil. Curitiba: Juruá, 1978.

MEIHY, José Carlos S. Bom. Manual de história oral. São Paulo: Loyola, 1996.

MULLET, Michael. A Contra-Reforma e a reforma católica nos princípios da Idade Moderna européia. Lisboa: Gradiva, 1984.

NADER, Maria Beatriz; FRANCO, Sebastião Pimentel; SILVA, Gilvan Ventura da (orgs). História, mulher e poder. Vitória: Edufes, 2006.

PINSKY, Carla Bassanezi e PEDRO, Joana Maria. Nova história das mulheres. São Paulo : Contexto, 2012.

SIQUEIRA, Maria da Penha Smarzaro. Industrialização e Empobrecimento Urbano. O Caso da Grande Vitória. 1950-1980. Vitória:EDUSP, 2002.

VAINFAS, Ronaldo. Casamento, amor e desejo no ocidente cristão. São Paulo: Ática, 1986.

VEYNE, Paul. O Império Romano. In: ARIÈS, Philippe; DUBY, George. História da vida privada. São Paulo: Companhia das Letras, 1989. p. 19-223.

FIBGE. Censo Demográfico do Espírito Santo, 1970.

FIBGE. Censo Demográfico do Espírito Santo, 1980.

ESPÍRITO SANTO (Estado). 1986. 
